This item was submitted to Loughborough's Research Repository by the author.

Items in Figshare are protected by copyright, with all rights reserved, unless otherwise indicated.

\title{
Population geography II: The r/age of migration
}

PLEASE CITE THE PUBLISHED VERSION

https://doi.org/10.1177/0309132518760098

PUBLISHER

SAGE $\odot$ The Author

VERSION

AM (Accepted Manuscript)

\section{PUBLISHER STATEMENT}

This work is made available according to the conditions of the Creative Commons Attribution-NonCommercialNoDerivatives 4.0 International (CC BY-NC-ND 4.0) licence. Full details of this licence are available at: https://creativecommons.org/licenses/by-nc-nd/4.0/

\section{LICENCE}

CC BY-NC-ND 4.0

\section{REPOSITORY RECORD}

Smith, Darren P.. 2019. "Population Geography II: The R/age of Migration”. figshare. https://hdl.handle.net/2134/28389. 


\title{
Population Geography II: \\ The 'rlage of migration'1
}

\author{
Darren P. Smith \\ Loughborough University
}

Keywords:

Immigration; international migration; population change; segregation; neighbourhood

\begin{abstract}
This second report focuses on the social impacts of migration in the context of the increasing politicization and contestation of migration. It is argued that Population Geography could engage in more effective ways with political debates of migration. A call is made for Population Geography to more readily provide robust evidence to shape debates, such as Brexit, and to inform the salience of 'raging comments' based on representations of migration as a harbinger of detrimental changes to local neighbourhoods. The discussion outlines scholarship from the UK and USA that progresses knowledge of changing population compositions and migration, to illustrate some ways that Population Geography can make valuable interventions within political, policy, media and lay discourses of migration. The paper concludes by highlighting some questions for Population Geography to reflect upon as a starting point for a more impactful Population Geography.
\end{abstract}

\section{Introduction}

In my previous report (Smith, 2018a), I highlighted work on population geographies of human trafficking. Connected, in part, to this scholarship, I want in this report to concentrate on population geographical research that has progressed understandings of the social impacts of migration. One of the

\footnotetext{
${ }^{1}$ The title is inspired by Castles et al. (1993).
} 
reasons for this focus is that the social effects of migration have been ratcheted-up as a grand public policy challenge for twenty-first century societies (Smith et al., 2016).

In the oft-cited 'age of migration', the transformative effects of contemporary migration on communities and neighbourhoods have vogue within media and political channels (Caviedes, 2015). Prevalent within many discourses are representations of migration as a cause of detrimental social change, tied to the consequences of increasing flows of unregulated population movements within and across national boundaries (Coleman and Stuesse, 2016). This is coupled to 'raging comments' for the strict control of migration in national policies, to halt or reduce overall rates of migration. Contrarily, there are, positive discourses of migration, which espouse virtues such as socio-cultural enrichment from diverse populations, and the economic benefits from lowercost, flexible labour of migrant populations (Favell, 2016).

In this melee of contestation, the paucity of empirical substantiations of the scale and effects of migration must be acknowledged. To date, the accuracy of some narratives of migration have not been effectively refuted or reaffirmed by scholarship. This is influenced by the absence of annual, up-to-date, (inter)national datasets that provide precise information on the flows and characteristics of migrants. National decadal census datasets are crosssectional, for example, and do not allow the comparison of annual trends. There are substantial 'black holes' within migration datasets over every decade, which have not been fully plugged by alternative datasets, such as International Passenger surveys (Rees, 2017). As a result, spatial and temporal mappings and comprehensive analyses of migration flows, including net, internal, and out-migration of social groups, are lacking.

These challenges intersect with thematic and methodological interests of Population Geography, and warrant the attention of the sub-discipline. Providing a fuller evidence-base of migration would enable the sub-discipline to have more impact on political, media and policy debates. As Boyle (2016) contends, Population Geography was silent in the debates of the Brexit 
referendum; despite 'leave' and 'remain' schools of thought contesting the effects of migration on social change (Wadsworth et al., 2016).

It would be a step-in-the-right direction to more fully expose local population compositions and changes in places that are, at least anecdotally, viewed as being transformed by migration. Although it might not be possible to pin down, in an accurate way, flows and characteristics of migration on an annual basis, it may be possible to identify overall population changes, and consider other factors for the transformation of local neighbourhood populations (such as fertility and ageing).

In the remainder of this report, recent Population Geography scholarship from the USA and UK is highlighted that has progressed knowledge of broader compositional changes to local population geographies. It is argued that this is important to more fully frame the effects of migration on social change, and offers the potential for Population Geography to inform political and policy debates such as Brexit. The discussion concludes with possible questions and future directions of travel for Population Geography in this field of study.

\section{Changing population geographies and contemporary migration}

According to some high profile commentators, migration is a harbinger of changing neighbourhood identities and senses of place. This view is often underpinned by vivid descriptions of migrant households settling in distinct residential enclaves, and imposing seemingly 'invasive' norms, lifestyles, living arrangements and ways of life within these neighbourhoods. Ostensible, dominant markers of migrant-led changes include expressions of unfamiliar: (foreign) languages; dress, music and embodiments; cultural consumption and related signage on streets (food and grocery shops, restaurants and cafes), and; religious institutions and festivals. It is claimed that established populations feel 'out of place' and 'othered', as rising proportions of migrant populations transfigure the overall ambience and 'feeling of the neighbourhood' (Meier, 2017). 
It is asserted that perceptions of changing places are reinforced by migrant populations conspicuously taking-over housing, work, environments for socialising (congregating in public spaces), and placing a burden on public services (schools, hospitals, dentists, health care, benefits). Tellingly, the United Kingdom Independent Party (UKIP) billboard posters in 2016 (in the lead-up to the Brexit Referendum) explicitly cited changing labour market conditions for settled populations (Dennison and Goodwin, 2015), with alarmist proclamations about the effects of immigration: '26 million people in Europe are looking for work. And whose jobs are they after?' (see Gagliardi and Lemos, 2015).

Processes of local population change are seen to be perpetuated via the outmigration (displacement / replacement) of established populations, has they 'take flight' in the midst of perceived and real changes to disappearing cultural structures and everyday life (Kaufmann and Harris, 2015), and feelings of loss and dispossession of belonging and attachment to place and community (Boschman and van Ham, 2015). Framed in this way, perceptions of migration can spark social unrest and conflict, and sociospatial divisions between settled and immigrant populations (i.e. 'parallel lives'). Ultimately, migration is treated as a phenomenon that creates segregated societies ('us' and 'them'), and undermines community cohesion and socially-mixed, diverse, local populations (Lewis et al., 2015; Zwiers et al., 2017); contrary to more positive readings of migration.

The emotive divisions and resentment between settled and migrant populations resonate with explanations of the formation of distinctive electorate voting practices (Johnston et al., 2016a). The exemplar of the USA Presidential election of Donald Trump (Johnston et al., 2016b), serves to highlight this point, with commentators stating that this reflects the attitudes of well-established (working class) populations to vote for symbolic change, in part, due to anxieties tied to perceptions of migrant groups taking-over their jobs, houses, schools and hospitals (Winders, 2016; Martin, 2017). Similar sentiments are evoked in the upsurge of votes for right-wing political parties 
and movements across Mainland Europe (e.g. Germany, France, Slovakia, Austria) (Halla et al., 2017).

The Brexit referendum in 2016 illustrates how the contested effects of migrants have become increasingly politicised in the UK (Harris and Charlton, 2016; Manley et al., 2017). Lay, media and political discourses of the Brexit referendum exemplify this point (Goodwin and Milazzo, 2017), shaped by the populist rhetoric of the UKIP (Bachmann and Sidaway, 2016), and other organisations. This is typified by verbatim quotes from the then Leader of UKIP, Nigel Farage, which include: 'parts of the country [UK] have "frankly become unrecognisable" and look "like a foreign land.... It was not until we got past Grove Park [in London] that I could hear English being audibly spoken in the carriage".

From a geographic perspective, the rhetorical statements of UKIP are targeted at two distinct geographies. First, there is a focus on neighbourhoods within London and large towns and cities, with claims that uncontrolled mass migration had allowed 'the growth of [Muslim] ghettos where the police and all the normal agents of the law have withdrawn and that is where Sharia Law has come in' (quoted in Independent, 14/01/15). Second, there is a concern with migrants from Accession 8 European nations into markets towns in Eastern England, such as Boston and Great Yarmouth (Burrell, 2016; Trevena et al., 2013). In these places, UKIP campaigns were founded on edicts, such as 'Catherine Blaiklock [candidate] asks... Do you recognise the Great Yarmouth you live in anymore?' (BBC, 30/5/2017).

What is surprising is that population geographers did not readily submit evidence to refute or reaffirm the geographic scale and magnitude of the effects of migration, particularly given the dearth of robust evidence was noted by 'leave' and 'remain' schools of thought. Advocates for the UK to remain in the European Union are critical that organisations calling for a controlled approach to immigration, such as Migration Watch, tend to 'release an alarming report about how many migrants are coming to the UK, or how much they cost UK taxpayers, and the press treats it like some respectable piece of 
academic research' (see Vargas-Silva, 2017). Similarly, in turn, Migration Watch (2017) stress the paucity of empirical evidence, highlighting a report by the Select Committee on Economic Affairs of the House of Lords (2008), as the 'only major inquiry ever conducted in the UK into the economic impact [of immigration]'.

A factor here may be that descriptive analyses of population distributions have been devalorised within the sub-discipline and beyond. It may be that Population Geography is more fixated on theorising processes of population, or sophisticating technical advances in data collection and manipulation. This may be influenced by an assumption that increasing on-line access to national datasets and user-friendly mapping software (Stillwell et al., 2015), and the development of research arms within non-academic institutions (Stillwell, 2015), mean that the mapping of populations is diminishing as part of remit of Population Geography (for exceptions see Lomax et al., 2014). Perhaps, there is also an implicit view that national research councils, in an evercompetitive landscape that stipulates the need for originality, innovation and outstanding scientific merit, may not fund this type of research activity.

Another reason for the lack of engagement with the Brexit referendum may have been the relative slow delivery of outputs from analyses of the 2011 UK Census, with the key collection by population geographers only recently being published (Stillwell, 2017). This sheds light on the effects of axes of social differences on population change, including ethnicity (e.g. Rees et al., 2017), social class (e.g. Dorling, 2017) and family structures (e.g. Smith and Culora, 2017), which could have shaped debates in the Brexit referendum (see also Champion et al., 2017). Likewise, in the following section, other Population Geography scholarship is highlighted that has the potential to inform ongoing debates of the effects of migration on social change.

\section{Progressing knowledge of changing population geographies}

Migration scholarship within Population Geography has hooked-up with the merits of assimilation, integration, super-diversity and minority-majority theories (e.g. Crul, 2015; Kivisto, 2017) in piecemeal ways. Nevertheless, it is 
recognised within the sub-discipline that compositional population characteristics influence how social changes, perceived to have been caused by migration, are experienced by settled populations (Lichter et al., 2017; van Heerden and Ruedin 2017). The sub-discipline is well tuned to investigate changes to compositional factors, including intersecting axes of social difference and uneven geographic patterns of ethnicity / race, religion, social class, education, lifecourse, affluence and poverty, places of origin and transit, and cultural norms. This is important given research is required to fully unpick how different forms and trajectories of local population diversity and / or homogeneity can influence (re)actions to migration-induced neighbourhood changes. Moreover, this begs specific questions that are being addressed by population geographers (e.g. Clark, 2016), such as:

- Is there less conflict and resistance from settled populations to increasing levels of migration in more historically, dynamic, socially-diverse neighbourhoods compared to more stable, socially-homogenous ones?

-Do the characteristics of specific migrant groups (i.e. language, dress, etc.) and / or established populations have a bearing on how migrants are 'accepted' and integrated into local neighbourhoods?

- Are the effects of migration experienced and perceived differently within diverse places on the rural-urban hierarchy?

-What are the effects of population density and scale (e.g. physical distance to the nearest neighbourhood with high proportions of migrants) on perceptions of migration?

Recent scholarship has clearly made progress here in deepening knowledge of population processes that are reshaping geographic patterns of segregation and diversity, with a prominent focus on ethnicity and race. Noteworthy are the contributions of Ellis, Wright, and colleagues in the USA. Ellis et al. (2014a), for instance, consider the possible effects of the 2008 economic recession on internal migration flows, to investigate if the diversification patterns of immigrants into non-traditional settlement locations (i.e. the plains, south, east coast of USA) in the 1990s were reproduced during the 2000s. Ellis et al. reveal the continuity of entrenched migration 
patterns before and post-recession, identifying that the internal movements of foreign-born populations into particular destination locations stayed the same (see also Goodwin-White, 2016).

Another strand of their work examines the impacts of new (im)migration controls for interstate movements, such as the effects on changing geographies of Latino populations (Ellis et al., 2016). Ellis et al. (2014b) reveal that settlement geographies of foreign-born populations are transformed by local and state immigration policies, with a sustained outmigration of foreign-born, non-citizen Latinos from Arizona following the enactment of the 2008 Legal Arizona Workers Act. These findings are emblematic of Rivers et al.'s (2015) findings in the U.S. South that 'a more nuanced set of interstate movements has emerged, differentiated by age and education within race groups' (p. 611).

Importantly, Wright et al.'s (2014) investigation of changing patterns of racial diversity and segregation finds that increasing ethnic and racial diversity is widespread at the multiple spatial scales. Describing a 'new mixtures of people' (p. 173), it is asserted that there is a close relationship between patterns of racial concentration and racial diversity. Wright et al. proclaim that diversity and segregation are not end points on a continuum, and that diversity and segregation are inter-related and should not be treated as dualisms (see also Ellis et al., 2017).

Advances in the understandings of the links between segregation, diversity and population change have also been forged in the UK. Finney and Jivraj's (2013) work is an exemplar of scholarship in Population Geography that is pertinent to debates of Brexit. First, Finney and Jivraj provide an excellent summary of current theoretical understandings of the linkages between community cohesion, neighbourhood belonging, population change, social mixing and diversity; citing the important earlier work of Bailey et al. (2012) and Livingston et al. (2010). Finney and Jivraj (2013) hypothesise that there are close relationships between high population turnover and low levels of belonging (exacerbated by high levels of ethnic diversity), which is further 
complicated by diverse compositional effects of neighbourhoods, such as deprivation. What is particularly relevant to political and policy debates are the empirical findings of Finney and Jivraj. Crucially, it is found that there would appear to be no strong relationships between population change, immigration and neighbourhood belonging. It is revealed that ethnicity is a key factor in variations of belonging, and, in particular, minority ethnic groups in neighbourhoods with high co-ethnic presence are identified as having strong levels of belonging. Finney and Jivraj also show that population movements within migration-induced population growth Minority and White areas are found to have the highest belonging to their neighbourhood. What this study serves to demonstrate is the need to transcend simplistic notions of segregation and social-mixing, and to more fully understand the diverse effects of the blending of different social groups in local neighbourhoods. Of course, Finney and Jivraj's analyses of 2005 and 2007 Citizenship Surveys of England and Wales may not have fully captured the migration and population dynamics that were central to the debates of Brexit. Nonetheless, their findings are important given a number of other studies in Population Geography have both confirmed and challenged representations of British society becoming more segregated.

From an age perspective, Sabater et al. (2017) argue that, at a national level in the UK, segregation between younger and older age groups increased between 1991-2001; rising most rapidly in some urban places. Explaining this residential segregation between young and old age groups, Sabater et al. note the endurance of North-South and Urban-Rural divides in the UK, with segregation most prominent in former industrial areas of the North of England.

Equally important are investigations of links between population change and settlement patterns of ethnic groups. Paramount here is the recent work of Johnston (2013) and colleagues (e.g. Harris et al., 2015; Johnston et al., 2015a; Jones et al., 2015). Johnston et al. (2013) draw attention to distinctive processes of population change that have given rise to: i) neighbourhoods in London, formerly dominated by White ethnic groups, becoming 'more mixed ethnically', and ii) neighbourhoods with low and diminishing White ethnic 
groups, that are not replaced by one Non-White ethnic group (see also Johnston et al., 2014). Johnston et al. (2013) thus highlight two trajectories of changing diversity underpinning the formation of contemporary landscapes of ethnicity.

Catney (2016a) argues that 'new spaces of diversity are emerging', calling for an acknowledgement of 'the more intricate spatial patterns and processes of ethnic group population change'. With this in mind, Catney shows how ethnic diversity in neighbourhoods is extending from pre-existing urban centres to locations that have previously been more socially homogeneous. In contrast to the thesis of increasing socio-spatial segregation along lines of ethnicity, Catney asserts that spatial mixing is on the rise, alongside the growth of minority ethnic groups in locations external to previous clustering. In a similar vein to Johnston et al., Catney finds that 'the coming years are likely to see continued mixing between people and within places', and, in addition, challenges the assertion of 'white flight' from increasingly ethnically diverse neighbourhoods. These trends are likely to have a bearing on how migrants are integrated into local neighbourhoods, and how effects of migration are perceived and experienced by populations (Catney, 2016b).

It is apparent that Population Geography scholarship is disentangling the intricate spatial patterns and processes of ethnic group population change, which is vital for framing how migration is perceived and experienced by different local populations in different places. Sapiro's (2017) investigation of the minority group migration flows of Arabs, Jews and Sikhs, drawing upon questions of ethnicity and religion in the UK 2011 census is illustrative of this direction of travel. Likewise, Shuttleworth (2012) argues that representations of growing communal or social segregation between Catholics and Protestants in Northern Ireland is not substantiated from analyses of national secondary datasets. Instead, Shuttleworth asserts that levels of communal or social segregation between Catholics and Protestants are relatively stable due to the lack of movement across the population, and migration flows being dominated by households moving short-distances and into and out of similar deprived places. 
Finally, Population Geography scholarship has shed light on the effects of living in ethnically diverse, socially-mixed neighbourhoods, compared to a more socially-homogenous ones. Feng et al.'s (2017) exploration of BME groups residing in high-density, own-ethnic group neighbourhoods, reveals a higher propensity for these groups to report poor health, but which are alleviated by individual and compositional effects of deprivation/affluence. Zuccotti and Platt (2016) explore the effects of concentrations of co-ethnics in neighbourhoods, and identify that social class and participation in the labour market is lowered for Pakistani and Bangladeshi females in neighbourhoods with high concentrations of co-ethnics, influenced by the 'cultural maintenance'. By contrast, Indian males have improved social class outcomes in neighbourhoods with high concentrations of co-ethnics, and this is seen to be illustrative of 'ethnic capital'.

Overall, what this scholarship from the USA and UK reveals are the dynamic and shifting processes of local population changes that are reconfiguring geographies of segregation and diversity. Understanding this changing framework is essential for grappling with the diverse perceptual and experiential outcomes of migration.

\section{Conclusion}

In this my second report, I have outlined Population Geography scholarship that has progressed understandings of local population compositions, with a focus on changing patterns of segregation and diversity. I have contended that this scholarship is important for more fully understanding the differential effects of migration on local communities and neighbourhoods. This provides a gateway for Population Geography to more fully engage with debates about the contested links between the effects of migration and neighbourhood change, such as the debates tied to the Brexit referendum and the USA Presidential election. The silence of Population Geographers in these

debates suggests that the sub-discipline could enhance the way that knowledge is exchanged with politicians, policy makers, the media and other 
stakeholders. As a starting point, there may be value in the sub-discipline reflecting on the following contentions that Population Geography may be:

- Addressing the 'wrong' kinds of research questions that are not of relevance to politicians, policy makers and the media

- Delivering the 'wrong' answers (albeit evidence-based) that policy makers 'do not want to hear', or do not chime with wider dominant political ideologies and priorities

- Employing the use of methods that are not viewed as being fully rigorous by policy makers, and producing an evidence-base that is challenged on the level of robustness

- Not effectively articulating and communicating research findings with nonacademic audiences, such as the over-inclusion of technical terms in policy briefings, and thus not effectively shaping public policy

- Lacking a high-profile, figure-head to champion the sub-discipline in the media and policy arenas.

- Experiencing the effects of a broader mistrust and lack of respect of academics by broader society and politicians.

Tellingly, it is notable that the Population Geography Research Group of the Royal Geographical Society recently launched a blog series with the aim: 'to promote timely and impactful dialogue on key political issues relating to population geography'. Positively, this suggests that many of the contentions, noted above, are digested and actioned by population geographers. When the next political debates on the effects of migration and social change are aired, Population Geography will be poised and ready to offer-up some empirically-grounded evidence to refute and / concur with political and media representations of migration.

\section{References}

Bachmann, V. and Sidaway, J.D., 2016. Brexit geopolitics. Geoforum, 77, pp.47-50. 
BBC (2017) Great Yarmouth Election Debate, 30 May. Available: http://www.bbc.co.uk/news/live/uk-england-norfolk-40043873

Boschman, S. and Van Ham, M., 2015. Neighbourhood selection of nonWestern ethnic minorities: testing the own-group effects hypothesis using a conditional logit model. Environment and Planning A, 47(5), pp.1155-1174.

Boyle, P., 2016. After-dinner keynote speech. $1^{\text {st }}$ International Conference on Migration and Mobilities (iMigMob). Loughborough University, 11-13 July.

Burrell, K. ed., 2016. Polish Migration to the UK in the 'new 'European Union: After 2004. Routledge.

Castles, S., De Haas, H. and Miller, M.J., 2013. The age of migration: International population movements in the modern world. Palgrave Macmillan.

Catney, G., 2016a. The changing geographies of ethnic diversity in England and Wales, 1991-2011. Population, Space and Place, 22(8), pp.750-765.

Catney, G., 2016b. Exploring a decade of small area ethnic (de-) segregation in England and Wales. Urban Studies, 53(8), pp.1691-1709.

Caviedes, A., 2015. An emerging 'European'news portrayal of immigration? Journal of Ethnic and Migration Studies, 41(6), pp.897-917.

Champion, T., Cooke, T.J., Shuttleworth, I. 2017. Internal Migration in the Developed World. Routledge.

Clark, W.A., 2017. Who Moves Into what Kinds of Neighbourhoods: Spatial Sorting and Integration. Tijdschrift voor economische en sociale geografie.

DOI: 10.1111/tesg.12264 
Coleman, M. and Stuesse, A., 2016. The Disappearing State and the QuasiEvent of Immigration Control. Antipode, 48(3), pp.524-543.

Crul, M., 2016. Super-diversity vs. assimilation: how complex diversity in majority-minority cities challenges the assumptions of assimilation. Journal of Ethnic and Migration Studies, 42(1), pp.54-68.

Dennison, J. and Goodwin, M., 2015. Immigration, issue ownership and the rise of UKIP. Parliamentary Affairs, 68(1), pp.168-187.

Dorling, D. 2017. Changes in Social Inequality, 2001-2011. In Stillwell, J. (Ed) The Routledge Handbook of Census Resources, Methods and Applications: Unlocking the UK 2011 Census.

Ellis, M., Wright, R., Townley, M., 2014a., The great recession and the allure of new immigrant destinations in the United States, International Migration Review, 48(1), pp. 3-33.

Ellis, M., Wright, R., Townley, M., Copeland, K.,2014b., The migration response to the Legal Arizona Workers Act, Political Geography, 42, pp. 4656.

Ellis, M., Wright, R., Townley, M., 2016., State-scale immigrant enforcement and Latino interstate migration in the United States, Annals of the Association of American Geographers, 106(4), pp. 891-908.

- Ellis, M., Wright, R., Holloway, S.R., Fiorio, L. 2017., Remaking white residential segregation: metropolitan diversity and neighbourhood change in the United States, Urban Geography. doi: 10.1080/02723638.2017.1360039 
Favell, A., 2016. Philosophies of integration: Immigration and the idea of citizenship in France and Britain. Springer.

Finney, N. and Jivraj, S., 2013. Ethnic group population change and neighbourhood belonging. Urban Studies, 50(16), pp.3323-3341.

Gagliardi, L. and Lemos, S., 2015. Evidence on immigrants' assimilation into recipient labour markets using UK longitudinal data between 1981 and 2006. Journal of Economic Geography, 16(3), pp.547-583.

Gietel- Basten, S., 2016. Why Brexit? The Toxic Mix of Immigration and Austerity. Population and Development Review, 42(4), pp.673-680.

Goodwin- White, J., 2016. Is Social Mobility Spatial? Characteristics of Immigrant Metros and Second Generation Outcomes: 1940-1970 and 19702000. Population, space and place, 22(8), pp.807-822.

Goodwin, M. and Milazzo, C., 2017. Taking back control? Investigating the role of immigration in the 2016 vote for Brexit. The British Journal of Politics and International Relations, 19(3), pp.450-464.

Halla, M., Wagner, A.F. and Zweimüller, J., 2017. Immigration and voting for the far right. Journal of the European Economic Association, 15(6), pp.13411385..

Harris, R., Johnston, R. and Manley, D., 2015. The changing interaction of ethnic and socio-economic segregation in England and Wales, 1991-2011. Ethnicities,17(3), pp.320-349.

Harris, R. and Charlton, M., 2016. Voting out of the European Union: Exploring the geography of Leave. Environment and Planning $A, 48(11)$, pp.2116-2128. 
Independent, 2015. Nigel Farage claims that Muslims are running UK 'ghettos' according to Sharia law, 14 January. Available:

http://www.independent.co.uk/news/world/europe/nigel-farage-claims-thereare-no-go-zones-for-non-muslims-in-french-cities-on-fox-news-9976907.html

Johnston, R., 2013. Multiethnic residential areas in a multiethnic country? A decade of major change in England and Wales. Environment and Planning $A$, 45(4), pp.753-759.

Johnston, R., Poulsen, M. and Forrest, J., 2014. London's changing ethnic landscape, 2001-2011: a cartographic exploration. Local Population Studies, 92(1), pp.38-57.

Johnston, R., Poulsen, M. and Forrest, J., 2015a. Increasing diversity within increasing diversity: the changing ethnic composition of London's neighbourhoods, 2001-2011. Population, Space and Place, 21(1), pp.38-53.

Johnston, R., Manley, D. and Jones, K., 2016a. Spatial Polarization of Presidential Voting in the United States, 1992-2012: The "Big Sort" Revisited. Annals of the American Association of Geographers, 106(5), pp.1047-1062.

Johnston, R., Jones, K., Manley, D. and Owen, D., 2016b. Macro-scale stability with micro-scale diversity: modelling changing ethnic minority residential segregation-London 2001-2011. Transactions of the Institute of British Geographers, 41(4), pp.389-402.

Jones, K., Johnston, R., Manley, D., Owen, D. and Charlton, C., 2015. Ethnic residential segregation: A multilevel, multigroup, multiscale approach exemplified by London in 2011. Demography, 52(6), pp.1995-2019.

Kaufmann, E. and Harris, G., 2015. "White Flight" or positive contact? Local diversity and attitudes to immigration in Britain. Comparative Political Studies, 48(12), pp.1563-1590. 
Kearns, A., Bailey, N., Gannon, M., Livingston, M. and Leyland, A., 2014. 'All in it together'? Social cohesion in a divided society: attitudes to income inequality and redistribution in a residential context. Journal of Social Policy, 43(3), pp.453-477.

Kilkey, M., Plomien, A. and Perrons, D., 2014. Migrant men's fathering narratives, practices and projects in national and transnational spaces: recent Polish male migrants to London. International Migration, 52(1), pp.178-191.

Kivisto, P., 2017. The origins of "new assimilation theory". Ethnic and Racial Studies, 40(9), pp.1418-1429.

Lewis, H., Dwyer, P., Hodkinson, S. and Waite, L., 2015. Hyper-precarious lives: Migrants, work and forced labour in the Global North. Progress in Human Geography, 39(5), pp.580-600.

Lichter, D.T., Parisi, D. and Taquino, M.C., 2017. Together but Apart: Do US Whites Live in Racially Diverse Cities and Neighborhoods?. Population and Development Review, 43(2), pp.229-255.

Lomax, N., Stillwell, J., Norman, P. and Rees, P., 2014. Internal migration in the United Kingdom: analysis of an estimated inter-district time series, 20012011. Applied Spatial Analysis and Policy, 7(1), pp.25-45.

Manley, D., Jones, K. and Johnston, R., 2017. The geography of Brexit-What geography? Modelling and predicting the outcome across 380 local authorities. Local Economy, 32(3), pp.183-203.

Martin, P.L., 2017. Election of Donald Trump and Migration. Migration Letters, 14(1), pp.161-171.

Meier, L., 2017. Three Types of Neighborhood Reactions to Local Immigration and New Refugee Settlements. City \& Community, 16(3), pp.252-256. 
Migration Watch (2017) What is the problem? Available: https://www.migrationwatchuk.org/what-is-the-problem

Rees, P., 2017. Immigration to the UK: the numbers game? Keynote public lecture, Institute of Advanced Studies, Loughborough University, 9 June.

Rees, P., Clark, S., Wohland, P., Lomax, N. and Norman, P. 2017. Using 2001 and 2011 Censuses to Reconcile Ethnic Group Estimates and Components for the Intervening Decade for English Local Authority Districts. In Stillwell, J. (Ed) The Routledge Handbook of Census Resources, Methods and Applications: Unlocking the UK 2011 Census

Rivers, N., Wright, R. and Ellis, M., 2015. The Great Recession and the Migration Redistribution of Blacks and Whites in the US South. Growth and Change, 46(4), pp.611-630.

Sabater, A., Graham, E. and Finney, N., 2017. The spatialities of ageing: Evidencing increasing spatial polarisation between older and younger adults in England and Wales. Demographic Research, 36, pp.731-744.

Shuttleworth, I., Barr, P.J. and Gould, M., 2013. Does internal migration in Northern Ireland increase religious and social segregation? Perspectives from the Northern Ireland longitudinal study (NILS) 2001-2007. Population, Space and Place, 19(1), pp.72-86.

Smith, D.P., Finney, N., Halfacree, N., and Walford, N., 2016. Introduction: 'On the move' in the twenty-first century and contemporary internal migration Internal Migration: Geographical Perspectives and Processes. Routledge, pp.11-14.

Smith, D.P., 2017. Population geography I: Human trafficking. Progress in Human Geography, doi: 10.1177/0309132516685196 
Smith, D.P. and Culora, A. 2017. Uneven Family Geographies in England and Wales: (Non)Traditionality and Change between 2001 and 2011. In Stillwell, J. (Ed) The Routledge Handbook of Census Resources, Methods and Applications: Unlocking the UK 2011 Census, Chapter 18.

Stillwell, J., 2015. Planning Support Systems. Applied Spatial Analysis and Policy, 8(2), pp.89-91.

Trevena, P., McGhee, D. and Heath, S., 2013. Location, Location? A Critical Examination of Patterns and Determinants of Internal Mobility Among Postaccession Polish Migrants in the UK. Population, Space and Place, 19(6), pp.671-687.

van Heerden, S. and Ruedin, D., 2017. How attitudes towards immigrants are shaped by residential context: The role of ethnic diversity dynamics and immigrant visibility. Urban Studies. doi.org/10.1177/0042098017732692.

Vargas-Silva, C. 2017. The fiscal impact of immigration in the UK. Available: http://www.migrationobservatory.ox.ac.uk/resources/briefings/the-fiscalimpact-of-immigration-in-the-uk/

Wadsworth, J., Dhingra, S., Ottaviano, G. and Van Reenen, J., 2016. Brexit and the Impact of Immigration on the UK. Centre for Economic Performance. LSE, pp.34-53.

Winders, J., 2016. Immigration and the 2016 Election. Southeastern Geographer, 56(3), pp.291-296.

Wright, R., Ellis, M., Holloway, S.R., Wong, S., 2014. Patterns of racial diversity and segregation in the United States: 1990-2010. The Professional Geographer, 66(2), pp. 173-182. 
Zuccotti, C. V., and Platt, L. 2017. Does Neighbourhood ethnic concentration in early life affect subsequent labour market outcomes? A study across ethnic groups in England and Wales. Population, Space and Place, 23(6).

Zwiers, M., Ham, M. and Manley, D., 2017. Trajectories of ethnic neighbourhood change: Spatial patterns of increasing ethnic diversity. Population, Space and Place. DOI: 10.1002/psp.2094 